Risueño Martínez, Jesús J.; Vázquez Pérez, María Luisa; Hidalgo Navarrete, José; De la Blanca de la Paz, Soledāa (2016). Language learning strategy use by spanish efl students: the effect of proficiency level, gender, and motivation. Revista de Investigación Educativa, 34(1), 133-149.

DOI: http://dx.doi.org/10.6018/rie.34.1.232981

\title{
Language learning strategy use by spanish efl students: the effect of proficiency level, gender, and motivation
}

\author{
El uso de estrategias de aprendizaje en estudiantes españoles de \\ inglés como lengua extranjera: el efecto del nivel de competencia, \\ el sexo y la motivación
}

Jesús J. Risueño Martínez*

María Luisa Vázquez Pérez*

José Hidalgo Navarrete*

Soledad de la Blanca de la Paz*

*Centro Universitario SAFA

Úbeda (adscrito a la Universidad de Jaén)

\begin{abstract}
This article aims to investigate the use of Language Learning Strategies (LLSs) by Spanish EFL students, as well as the relationship between that use and other learner variables such as the proficiency level, gender, and motivation. Participants were 206 Spanish students of English from different proficiency levels. The instrument used to collect data was a questionnaire.

The results show that the participants use LLSs moderately with a high preference for metacognitive and affective strategies. Proficiency level did not have a significant effect, except in the cognitive category between proficient and basic users groups. In relation to gender, there were not statistically significant differences between male and female students. However, motivation had a paramount effect in the use of LLSs.
\end{abstract}

Keywords: learning strategies, proficiency level, gender, motivation.

Correspondencia: Jesús J. Risueño Martínez (jrisueno@fundacionsafa.es); María Luisa Vázquez Pérez (mlvazquez@fundacionsafa.es); José Hidalgo Navarrete (josehidalgo@fundacionsafa.es); Soledad de la Blanca de la Paz (sblanca@fundacionsafa.es) 


\section{Resumen}

El propósito de este estudio es investigar el uso de las estrategias de aprendizaje de la lengua extranjera por parte de estudiantes de inglés con distintos niveles de competencia. Además, intenta explorar la relación que pueda haber entre ese uso y otras variables como el nivel de competencia, el sexo y la motivación. Se ha utilizado un cuestionario para la obtención de los datos. Los resultados indican que nuestros participantes $(N=206)$ hacen un uso moderado de esas estrategias, siendo las más utilizadas las metacognitivas y las afectivas. El nivel de competencia sólo tuvo un impacto significativo en la categoría de estrategias cognitivas entre los estudiantes del nivel más alto y los de los niveles básicos. No se encontraron diferencias significativas entre las mujeres y los hombres en el uso de las estrategias. Sin embargo, el factor motivacional sí arrojó diferencias significativas.

Palabras clave: estrategias de aprendizaje, nivel de competencia, sexo, motivación.

\section{Introduction}

In the last decades, research into the field of second and foreign language acquisition (or learning) has changed the focus from teaching to learning, that is, from instructional methods to learner's characteristics. Learners are considered active participants in their learning process, and this shift in the perspective has fostered a great body of research about how learners acquire the L2, their individual differences, learning styles, in short, what makes them successful learners. In this sense, there has been a greater interest in how individual learners approach and manage their own learning and what kind of strategies they employ.

Initially, early studies about language learning strategies (LLSs) tried to identify the strategies that learners use while learning a L2, and classify them (Cohen, 1990; O’Malley \& Chamot, 1990; Oxford, 1990; Rubin, 1975; Wenden \& Rubin, 1987). More recent research has devoted its attention to determine the relationship between the use of LLSs and other learner variables such as the age, the proficiency level, the gender, or the motivation. Although there are some general assumptions about the relationship between those variables and LLSs, we have to be cautious about drawing definitive conclusions, as the results vary greatly depending on the context, the participants, or the instruments used.

Despite a great number of studies that have investigated LLSs in other countries, in the case of Spain, there are a few studies which have focused their attention to explore the use of LLSs by Spanish EFL learners (Franco Naranjo, 2004; Franco Naranjo, Pino Juste, \& Rodríguez López, 2009; García Herrero, 2013), or their effect on the proficiency level (Franco Naranjo, Bocanegra Valle, \& Díaz Martín, 2003; García Herrero \& Jiménez Vivas, 2014), or gender (Corpas Arellano, 2010). We consider that this area has not been investigated enough and, therefore, needs more attention, especially the relationship between LLSs and other learner variables such as gender or motivation.

Thus, the purpose of the current study is to shed more light on this area of research by exploring the use of LLSs by Spanish EFL learners who attend intensive English language courses. Moreover, we intend to study the effects of LLSs on other learner variables which are supposed to affect the process of language learning and the variation and preference in the use of strategies: proficiency level, gender, and motivation. 


\section{Language learning strategies}

\section{Definition and classification}

There has not been a unique definition of the concept unanimously accepted by all of the authors in the field and the terminology varies from one to another. As Ellis (1994) claims "The concept of strategy is a somewhat fuzzy one, and, (...) not easy to tie down" (p. 529).

One of the problems is how the authors consider the nature of the strategies. Analyzing some definitions of LLSs, Ellis (1994) identifies this aspect: "It is not clear whether they are perceived of as behavioral (and, therefore, observable) or as mental, or as both" (p. 531).

Another issue is the conscious aspect, that is, if the learners use the strategies intentionally o subconsciously. According to Oxford, strategies are "specific actions, behaviors, steps, or techniques students use, often consciously, to improve their progress in apprehending, internalizing, and using the L2" (Oxford, 2002, p. 18). Chamot (2004) defines learning strategies as "the conscious thoughts and actions that learners take in order to achieve a learning goal" (p. 14). Both authors coincide on the behavioral and conscious aspects in their definitions. Learners use the strategies consciously, and for this reason they can identify them. This is a key factor when trying to carry out a study on learning strategies because that conscious knowledge allows the learners to report the strategies used, and, therefore, to control and improve their own learning approaches (Chamot, 2004; Grenfell \& Macaro, 2007; O'Malley \& Chamot, 1990; Oxford, 1990).

There is not a single taxonomy of learning strategies either; however, most proposals are not very different and have many aspects in common. Some of the most known classifications are those by Cohen (1998), O'Malley \& Chamot (1990), and Rubin (1987). But perhaps the most acknowledged and referenced taxonomy is that of Oxford's (1990). Her classification is considered the most detailed and systematic and superior to other ones "in accounting for the variety of strategies reported by language learners" (Hsiao \& Oxford, cited in Chamot, 2004, p. 17). Oxford considers two main classes of language strategies, direct and indirect, which are further divided into six broad categories (Oxford, 1990, p. 17):

\section{DIRECT STRATEGIES}

- Memory strategies (creating mental linkages, applying images and sounds, reviewing well, employing action)

- Cognitive strategies (practicing, analyzing and reasoning)

- Compensation strategies (guessing, overcoming communication problems)

\section{INDIRECT STRATEGIES}

- Metacognitive strategies (centering, planning, and evaluating the learning)

- Affective Strategies (controlling feelings and emotions)

- Social strategies (interacting with others) 


\section{LLSs and learners variables}

Apart from investigating the kind of strategies which learners use and how those strategies can be classified, there has been a growing number of studies which have devoted their attention to determine the relationship between the use of LLSs and other learner variables such as the proficiency level, gender, or motivation.

\section{LLSs and proficiency level}

Many authors have focused their studies on the relationship between the strategy use and learners' language competence or proficiency level. Most of those studies show a positive relationship between both variables giving evidences that the students with the highest level of language competence use a greater number of strategies more frequently and in a more effective way than those with a lower level (Al-Buainain, 2010; Alhaisoni, 2012; Franco Naranjo et al., 2003; García Herrero \& Jiménez Vivas, 2014; Hong-Nam \& Leavell, 2006; Wharton, 2000; Wu, 2008).

Since the general assumption has been that there is a direct relationship between LLSs and the proficiency level, most of the authors agree that strategy training can be beneficial to improve the learners' competence in the L2 (Liu, 2010; García Salinas \& Ferreira Cabrera, 2010).

\section{LLSs and gender}

Many researchers have given evidences of a significant variation in strategy use due to gender. The results have usually showed that female learners use LLSs more frequently than male ones, supporting the general idea that females are superior to males in language learning. More recently there have been a number of studies supporting the superiority of female learners in overall strategy use, and in specific categories (Alhaisoni, 2012; C.-Y. Chang, Liu, \& Lee, 2007; Corpas Arellano, 2010; Ghee, Ismail, \& Kabilan, 2010; Hong-Nam \& Leavell, 2006; Kavasoglu, 2009; Khalil, 2005; Radwan, 2011; Zhou \& Intaraprasert, 2015).

However, some studies show no significant differences between males and females in the use of LLSs (Lou, 1998; Peng, 2001; Vandergrift, 1997), or that males do better than females in some strategies (Ghani, 2003; Tercanlioglu, 2004; Wharton, 2000).

\section{LLSs and motivation}

The relationship between motivation and LLSs has been another field on which different researchers have focused their attention. The general assumption, supported by most of the studies, is that there is a reciprocal relationship between these two variables in the sense that motivation leads to strategy use, and strategy use to motivation. As McDonough (2005) and Wenden (1991) claim, training in the use of learning strategies has a positive effect on learners' motivation, increasing self-steem and autonomy. 
Some recent studies have given evidences of that significant relationship between motivation and the use of learning strategies, showing that more motivated learners use more and a wider range of LLSs (Benson \& Gao, 2008; H.-H. Chang, 2005; Ghavamnia, Kassaian, \& Dabaghi, 2011; Yin, 2008). Other studies also show that specific types of motivation are associated (or not) to strategy use. Feng (2010) reported that more motivated participants used more LLSs, especially cognitive, social and memory strategies. Nikoopour, Salimian, Salimian, \& Farsani (2012) found a positive and significant relationship between intrinsic motivation (the most autonomous type of motivation driven by the individual interest or enjoyment, not derived from external factors) and metacognitive and cognitive strategies, while different types of extrinsic (external) motivation were not significantly associated with the use of LLSs. Similar results were found by Luo \& Jian (2004), Xu (2011), and Ziahosseini \& Salehi (2007).

\section{Objectives}

The main aims of this study were to explore:

1) which categories of LLSs are used most frequently by Spanish EFL learners,

2) whether there is any significant relationship between LLSs use and proficiency level,

3) whether there is any significant relationship between LLSs use and gender, and

4) whether there is any significant relationship between LLSs use and motivation.

\section{Method}

\section{Participants}

The participants were 206 Spanish students of English as a Foreign Language with different proficiency levels who were attending intensive English courses at the Modern Language Centre "Jesús Mendoza" (CLM) in Úbeda, Jaén. The CLM "Jesús Mendoza" belongs to the Sagrada Familia University Centre, a university institution which has been training teachers for more than 70 years. The CLM offers English courses according to the different competence levels described in the Common European Framework of Reference for languages (CEFR): basic user (A1 and A2), independent user (B1 and B2) and proficient user (C1). The CLM is a registered examination centre of Trinity College of London.

141 students were women $(68.4 \%)$ and 65 men $(31.6 \%)$. The average age was 27.73 years old, 13 being the minimum age and 60 the maximum. According to the proficiency level, 60 students (21.9\%) were in the basic user levels, $126(61.2 \%)$ in the independent user levels (58 in B1 and 68 in B2), and 20 (9.7\%) in the proficient user level (C1). For the purpose of the current study, the participants were divided into four groups: basic users (A1 and A2), independent users 1 (B1), independent users 2 (B2), and proficient users (C1).

With respect to the occupation, the most frequent is student (74), followed by teachers (65); 16 are unemployed, and the rest practice other occupations with a less incidence. 
In order to know the reasons that the participants had to learn English and, therefore, their motivation, they were asked why they were learning English. The possible options were: a) because I need it, b) for pleasure, because I like it, and c) both reasons. $49.5 \%$ of the participants declared that necessity was the main reason (to get a degree, for a job...), only $2.4 \%$ of the participants answered that they were doing it for pleasure, and $48.1 \%$ chose both reasons. Option a) can be related to a type of external, extrinsic motivation, option b) to some kind of intrinsic motivation, and option c) a mix of both types. To analyze the possible relationship between motivation and LLSs, the participants were divided into three groups according to their reason to learn English: extrinsic, intrinsic, and extrinsic/intrinsic motivation.

\section{Instrument and procedure}

The instrument used to collect information on strategy use was a questionnaire (see Risueño Martínez, Vázquez Pérez, Hidalgo Navarrete, \& de la Blanca de la Paz, 2014). It was adapted from the Strategy Inventory for Language Learning, SILL, (Oxford, 1990) version 7.0 (ESL/EFL) and the questionnaires designed by Franco Naranjo, Pino Juste \& Rodríguez López (2012) and Roncel Vega (2007). The first part of the questionnaire was a set of personal data about the participants: sex, age, proficiency level, studies, occupation, and the reason why they were learning English. The second part was related to the LLSs and it consisted of 55 items (strategies) classified into the Oxford's six known categories: memory (items1-9), cognitive (items 10-25), compensation (items 26-30), metacognitive (items 31-40), affective (items 41-49), and social (items 50-55). It was a Likert scale to measure the frequency of strategy use: 1 "No, never", 2 "Very few times", 3 "Sometimes", 4 "Most of the times", and 5 "Always". A range of 1.0-2.4 is considered as low frequency of use, 2.5-3.4 medium use, and 3.5-5 as high frequency of use. The items were in Spanish to make sure that the participants had no problems in understanding them.

The questionnaire was on line and the participants carried it out in the classroom with the researchers. They needed 10-15 minutes to complete it. They declared no special difficulty to carry it out although the researchers answered any questions or resolved any doubts that they had. The process of completing the questionnaire took place in December 2014.

For the purpose of the present study, 20 participants were administered the questionnaire as a pilot study. The reliability index based on Cronbach's alpha for this questionnaire was 0.89 .

\section{Statistical analyses}

To check data and parametric assumptions, preliminary and exploratory analyses were conducted. The parametric assumption of normality was not met for some variables (Kolmogorof-Smirnov test $p<0.05$ ), but Levene's tests confirmed homoscedasticity $(p>0.05)$. Hence, parametric tests were run. Concretely, descriptive analyses, ANOVAs and $t$ tests for mean differences, Pearson's correlations and stepwise multiple linear regression analyses were run. 


\section{Results and discussion}

\section{Overall use}

The global mean for the individual strategies in each category was calculated. The results showed that the LLSs overall use of participants was medium to high with mean statistics ranging between $\mathrm{M}=3.75$ and $\mathrm{M}=2.88$ and a mean in overall use of 3.37 (table 1.). This result is in line with other recent studies in Spain and other countries (Feng, 2010; Franco Naranjo et al., 2003; Franco Naranjo et al., 2009; García Herrero, 2013; García Herrero \& Jiménez Vivas, 2014; Ghavamnia, et al., 2011; Hong-Nam \& Leavell, 2006; Kavasoglu, 2009; Nikoopour et al., 2012; Razak \& Babikkoi, 2014; Zhou \& Intaraprasert, 2015). The scores in the different categories indicate a positive attitude towards the use of LLSs among the participants while learning English as a foreign language.

With regard to each specific category of strategies, different frequencies of use can be observed (Table 1). If we consider the mean in each of the six categories, we can see that none of them present a low frequency of use (1.0-2.4).

Table 1

Frequency of use of the six LLSs categories

\begin{tabular}{lccccc}
\hline & N & Mín & Max & Mean & SD \\
\hline METACOGNITIVE & 206 & 2.30 & 4.90 & 3.75 & .588 \\
AFFECTIVE & 206 & 2.00 & 5.00 & 3.71 & .589 \\
COMPENSATION & 206 & 1.67 & 5.00 & 3.35 & .666 \\
SOCIAL & 206 & 1.88 & 4.44 & 3.27 & .450 \\
COGNITIVE & 206 & 1.67 & 4.00 & 3.25 & .491 \\
MEMORY & 206 & 1.29 & 3.43 & 2.88 & .366 \\
OVERALL & & & & & .630 \\
\hline
\end{tabular}

Metacognitive strategies were reported to be used more than the other categories of strategies with a high frequency of use (3.75). Our participants are aware of their own process of learning and try to control it. These findings are consistent with other studies (Franco Naranjo et al., 2003; Franco Naranjo et al., 2009; García Herrero \& Jiménez Vivas, 2014; Hong-Nam \& Leavell, 2006; Kavasoglu, 2009; Lee \& Oxford, 2008; Magogwe \& Oliver, 2007; Nikoopour, Amini Farsani, \& Kashefi Neishabouri, 2011; Nikoopour et al. 2012; Takeuchi, 2003; Wharton, 2000; Xu, 2011).

The least frequently used category reported by the participants was memory strategies with a mean of 2.88. This finding is in line with results in other studies (Al-Buainain, 2010; Alhaisoni, 2012; C. Chang, 2011; García Herrero, 2013; García Herrero \& Jiménez Vivas, 2014; Hong-Nam \& Leavell, 2006; Nikoopour et al. 2011; Yang, 2007). 


\section{Proficiency level}

With regard to the effect of proficiency level on the overall use of LLSs, we can observe that the participants in the basic users, independent users 1 and independent users 2 groups reported a medium use of strategies $(M=3.34, M=3.35$, and $M=3.36$ respectively) while the participants in the proficient users group showed a high use of strategies $(\mathrm{M}=3.52)$, supporting the idea that more proficient learners use LLSs more frequently than those in lower proficiency levels. The proficient students also reported a greater use of strategies in all categories with the exception of memory strategies, which show a similar frequency of use than the basic users. The highest and lowest frequency of use was in the metacognitive and memory category respectively in all groups (Table 2).

With the purpose of finding out whether there were statistically significant differences in the use of strategies among the four groups, a one-way Anova between groups analysis was carried out (Table 2 and Table 3). The results revealed no statically significant differences in the use of any of the six categories of strategies, except in the cognitive category where $p$ value was very close to significance level $(p=.052)$. The Tukey HSD test for pairwise comparison revealed significant differences in the pair proficient users and basic users groups. Proficient students reported using these strategies significantly more often than basic users (Table 3). Highly proficient learners seem to have a more conscious control of their learning, and they use cognitive strategies in order to develop their language system.

Table 2

Proficiency level: overall use and frequency in the different categories

\begin{tabular}{lcccccccccc}
\hline Categories & \multicolumn{2}{c}{$\begin{array}{c}\text { Basic user } \\
(\mathrm{N}=60)\end{array}$} & \multicolumn{2}{c}{$\begin{array}{c}\text { Ind. user 1 } \\
(\mathrm{N}=58)\end{array}$} & \multicolumn{2}{c}{$\begin{array}{c}\text { Ind. user 2 } \\
(\mathrm{N}=68)\end{array}$} & \multicolumn{2}{c}{$\begin{array}{c}\text { Proficient user } \\
(\mathrm{N}=20)\end{array}$} \\
& Mean & S.D. & Mean & S.D. & Mean & S.D. & Mean & S.D. & F & Sig. \\
\hline MEMORY & 2.93 & .458 & 2.82 & .484 & 2.88 & .508 & 2.93 & .566 & .525 & .666 \\
COGNITIVE & 3.17 & .426 & 3.26 & .422 & 3.24 & .476 & 3.49 & .461 & 2.622 & .052 \\
COMPENSATION & 3.31 & .534 & 3.24 & .487 & 3.41 & .492 & 3.55 & .535 & 2.332 & .075 \\
METACOGNITIVE & 3.73 & .568 & 3.78 & .580 & 3.71 & .618 & 3.85 & .594 & .323 & .808 \\
AFFECTIVE & 3.71 & .581 & 3.74 & .568 & 3.64 & .650 & 3.82 & .455 & .659 & .578 \\
SOCIAL & 3.19 & .638 & 3.28 & .649 & 3.27 & .723 & 3.47 & .596 & .863 & .461 \\
& & & & & & & & & & \\
OVERALL USE & 3.34 & .320 & 3.35 & .358 & 3.36 & .303 & 3.52 & .332 & & \\
\hline
\end{tabular}

These results are not consistent with the studies mentioned before which revealed that proficiency level had a significant effect on the overall strategy use as well as on the different categories (Al-Buainain, 2010; Alhaisoni, 2012; Franco Naranjo et al., 2003; Hong-Nam \& Leavell, 2006). However, the findings in the current study are in line with those in the study by García Herrero \& Jiménez Vivas (2014) in which high level students employed cognitive strategies significantly more than students in the lowest level. 
Table 3

Proficiency level: one-way Anova analysis. Cognitive category

\begin{tabular}{cllccccc}
\hline \multirow{2}{*}{$\begin{array}{c}\text { Dependent } \\
\text { Variable }\end{array}$} & (I) LEVEL & (J) LEVEL & $\begin{array}{c}\text { Mean } \\
\text { Difference (I-J) }\end{array}$ & $\begin{array}{c}\text { Std. } \\
\text { Error }\end{array}$ & Sig. & \multicolumn{2}{c}{$\begin{array}{c}\text { 95\% Confidence } \\
\text { Interval for Mean }\end{array}$} \\
\hline \multirow{5}{*}{ COGNITIVE } & Basic & Indep 1 & -.08463 & .08198 & .731 & -.2970 & .1277 \\
& Bower & $\begin{array}{c}\text { Upper } \\
\text { Bound }\end{array}$ \\
& Basic & Indep 2 & -.06422 & .07886 & .848 & -.2685 & .1401 \\
& Basic & Proficient & $-.32083^{*}$ & .11495 & $.029^{*}$ & -.6186 & -.0230 \\
& Indep 1 & Indep 2 & .02041 & .07958 & .994 & -.1857 & .2266 \\
& Indep 1 & Proficient & -.23621 & .11545 & .175 & -.5353 & .0629 \\
& Indep 2 & Proficient & -.25662 & .11325 & .110 & -.5500 & .0368 \\
\hline
\end{tabular}

One possible explanation for these results is the fact that most of the participants in our study were adult learners, and, as Franco Naranjo et al. (2009) point out, they have had previous academic experiences and can transfer the use of effective strategies employed in other previous learning contexts. Additionally, most of them were students who were being trained to be teachers of primary and childhood education, and practicing teachers, and because of this educational environment, they could be aware of (and familiar with) learning strategies either because they were trained in their use by their own university teachers (students), or because they (teachers) also taught their students some general learning strategies.

\section{Gender}

Both groups presented a medium use of strategies with very similar means in all categories (Table 4). The most frequently used category reported by female students was metacognitive $(\mathrm{M}=3.79)$, while male students declared using affective strategies most frequently $(\mathrm{M}=3.71)$. In both groups the category of strategies least frequently used was memory $(\mathrm{M}=2.86$ and $\mathrm{M}=2.92)$.

Many studies have given evidences that females seem to use a wider range of strategies than males (Alhaisoni, 2012; C.-Y. Chang et al., 2007; Corpas Arellano, 2010; Ghee et al., 2010; Hong-Nam \& Leavell, 2006; Kavasoglu, 2009; Khalil, 2005; Radwan, 2011; Zhou \& Intaraprasert, 2015). An independent samples t-test was carried out to determine whether there were statistically significant differences between male and female participants in strategy use. Surprisingly, the results in the current study revealed that there were not statistically significant differences neither in overall use nor in any of the six categories (Table 4). These results were not expected since, as previously mentioned, the general assumption is that females are better than males in the use of LLSs, although there are some studies which also revealed no significant gender differences (Lou, 1998; Peng, 2001; Vandergrift, 1997). 
As with the results in proficiency level, the fact that a great majority of the participants, males and females, were adults related to the teaching field in one way or another (teacher trainees and practicing teachers) may have had an important role in the way our participants perceive and use the LLSs.

Table 4

Gender: overall use and frequency in the different categories

\begin{tabular}{lcccccc}
\hline \multirow{2}{*}{ Categories } & \multicolumn{2}{c}{$\begin{array}{c}\text { Females } \\
(\mathrm{N}=141)\end{array}$} & \multicolumn{2}{c}{ Males } \\
& Mean & S.D. & Mean & S.D. & t & Sig. \\
\hline MEMORY & 2.86 & .494 & 2.92 & .486 & .859 & .391 \\
COGNITIVE & 3.26 & .490 & 3.24 & .351 & -.282 & .778 \\
COMPENSATION & 3.35 & .548 & 3.34 & .428 & -.125 & .900 \\
METACOGNITIVE & 3.79 & .552 & 3.65 & .652 & 1.628 & .105 \\
AFFECTIVE & 3.70 & .588 & 3.71 & .598 & .075 & .941 \\
SOCIAL & 3.26 & .666 & 3.30 & .671 & .423 & .673 \\
& & & & & & \\
OVERALL USE & 3.37 & .338 & 3.36 & .289 & & \\
\hline
\end{tabular}

\section{Motivation}

Regarding the effect of motivation on the overall use of language strategies (Table 5), the intrinsically motivated participants reported the highest use of strategies with a mean of 3.65. The students in the extrinsic/intrinsic group also showed a high frequency of use $(M=3.48)$, while extrinsically oriented learners reported a medium use with the lowest mean (3.25). Intrinsic and extrinsic/intrinsic groups also got higher scores than the extrinsic group in all categories. All groups reported the highest frequency of use in metacognitive strategies and the lowest frequency in the memory category.

The results of the one-way Anova between groups analysis revealed statistically significant differences in the cognitive, metacognitive, affective, and social categories (Table 6). In the last three categories the differences were in the pair extrinsic-extrinsic/ intrinsic, which means that those participants who were externally and internally motivated used the strategies in these categories significantly more frequently that those who were only extrinsically motivated. In the cognitive category the differences were in the pairs extrinsic-extrinsic/intrinsic and extrinsic-intrinsic, which reinforces the idea that intrinsic motivation was the factor which made the difference in the frequency of use of the strategies reported by the participants in our study.

These findings support the idea that intrinsic motivation seems to have a greater effect on strategy use than extrinsic motivation (Luo \& Jian, 2004; Nikoopour et al., 2012; Xu, 2011; Ziahosseini \& Salehi, 2007). In our study, learners who are inherently motivated in learning English use cognitive, metacognitive, affective, and social strategies more frequently than those who are only extrinsically motivated. 
Table 5

Motivation: overall use and frequency in the different categories

\begin{tabular}{lcccccccc}
\hline \multirow{2}{*}{ Categories } & \multicolumn{2}{c}{$\begin{array}{c}\text { Extrinsic } \\
(\mathrm{N}=102)\end{array}$} & \multicolumn{2}{c}{$\begin{array}{c}\text { Intrinsic } \\
(\mathrm{N}=5)\end{array}$} & \multicolumn{2}{c}{$\begin{array}{c}\text { Extr./intr. } \\
(\mathrm{N}=99)\end{array}$} \\
& Mean & S.D. & Mean & S.D. & Mean & S.D. & F & Sig. \\
\hline MEMORY & 2.81 & .466 & 3.24 & .433 & 2.94 & .508 & 3.207 & $.043^{*}$ \\
COGNITIVE & 3.12 & .382 & 3.59 & .344 & 3.37 & .480 & 10.064 & $.000^{*}$ \\
COMPENSATION & 3.32 & .496 & 3.64 & .590 & 3.36 & .525 & .946 & .390 \\
METACOGNITIVE & 3.64 & .577 & 4.04 & .826 & 3.84 & .572 & 3.608 & $.029^{*}$ \\
AFFECTIVE & 3.50 & .580 & 3.93 & .488 & 3.91 & .529 & 14.492 & $.000^{*}$ \\
SOCIAL & 3.06 & .582 & 3.47 & .594 & 3.48 & .687 & 11.284 & $.000^{*}$ \\
& & & & & & & & \\
OVERALL USE & 3.25 & .307 & 3.65 & .295 & 3.48 & .358 & & \\
\hline
\end{tabular}

Table 6

Motivation: one-way Anova analysis

\begin{tabular}{|c|c|c|c|c|c|c|c|}
\hline \multirow{2}{*}{ Dependent Variable } & \multirow{2}{*}{$\begin{array}{c}\text { (I) } \\
\text { Motivation }\end{array}$} & \multirow{2}{*}{$\begin{array}{c}(\mathrm{J}) \\
\text { Motivation }\end{array}$} & \multirow{2}{*}{$\begin{array}{c}\text { Mean } \\
\text { Difference } \\
(\mathrm{I}-\mathrm{J})\end{array}$} & \multirow{2}{*}{$\begin{array}{l}\text { Std. } \\
\text { Error }\end{array}$} & \multirow{2}{*}{ Sig. } & \multicolumn{2}{|c|}{$\begin{array}{l}\text { 95\% Confidence } \\
\text { Interval for Mean }\end{array}$} \\
\hline & & & & & & $\begin{array}{l}\text { Lower } \\
\text { Bound }\end{array}$ & $\begin{array}{l}\text { Lower } \\
\text { Bound }\end{array}$ \\
\hline \multirow{3}{*}{ COGNITIVE } & Extrinsic & Intrinsic & $-.47047^{*}$ & .19777 & .048 & -.9374 & -.0035 \\
\hline & Extrinsic & Extr.-Intr. & $-.25102^{*}$ & .06092 & .000 & -.3948 & -.1072 \\
\hline & Intrinsic & Extr.-Intr. & -.21944 & .19791 & .510 & -.6867 & .2478 \\
\hline \multirow{3}{*}{ METACOGNITIVE } & Extrinsic & Intrinsic & -.39686 & .26585 & .297 & -1.0245 & .2308 \\
\hline & Extrinsic & Extr.-Intr. & $-.19929^{*}$ & .08189 & .042 & -.3926 & -.0060 \\
\hline & Intrinsic & Extr.-Intr. & .19758 & .26604 & .738 & -.4305 & .8257 \\
\hline \multirow{3}{*}{ AFFECTIVE } & Extrinsic & Intrinsic & -.43660 & .25381 & .200 & -1.0358 & .1626 \\
\hline & Extrinsic & Extr.-Intr. & $-.41460^{*}$ & .07818 & .000 & -.5992 & -.2300 \\
\hline & Intrinsic & Extr.-Intr. & .02200 & .25398 & .996 & -.5777 & .6217 \\
\hline \multirow{3}{*}{ SOCIAL } & Extrinsic & Intrinsic & -.40784 & .29085 & .342 & -1.0946 & .2789 \\
\hline & Extrinsic & Extr.-Intr. & $-.42097^{*}$ & .08959 & .000 & -.6325 & -.2095 \\
\hline & Intrinsic & Extr.-Intr. & -.01313 & .29106 & .999 & -.7003 & .6741 \\
\hline
\end{tabular}

\section{Conclusion}

The purpose of the current study was to investigate the LLS use of Spanish EFL students who were attending different intensive English courses. We also wanted to explore if there were any possible relationships between that LLS use and other factors that have been found to affect strategy use such as proficiency level, gender and motivation. 
The results showed that our participants reported a medium to high overall use of strategies. The results also revealed a high preference for metacognitive and affective strategies. It seems that our participants have identified these two types of strategies and they try to use them to facilitate their process of learning the foreign language. The least preferred strategies were memory strategies. As in other studies mentioned, our participants use the strategies related to the storage and retrieval of information after using other types of strategies.

With regard to the relationship between proficiency level and LLS use, the findings in our study showed that the participants in the highest proficiency level reported a higher frequency in overall use and in each specific category than the students in the rest of the groups, with the exception of the memory category in which proficient learners and basic users group reported a similar frequency of use.

Unlike other studies, proficiency level did not have a significant effect on the overall strategy use and on the different categories, except in the cognitive category, where proficient students reported using these strategies significantly more often than basic users. This may indicate that a higher use of cognitive strategies fosters foreign language acquisition, leading to a higher competence.

Many studies have found that female learners are better than male learners in the use of LLSs, employing a wider range of strategies. That is not the case of the current study as the results revealed that there were not statistically significant differences neither in overall use nor in any of the categories between both groups. Those findings give evidence that there is not a complete agreement on the matter, as we can find mixed results of the effect of gender on LLSs, with studies which found significant differences in favor of females, studies in which males were superior, and some others which found no significant differences, as it is the case of our study.

Regarding the effect of motivation on LLS use, the findings in the current study revealed that motivation has a main effect in the way learners employ the LLSs. Intrinsically and extrinsically-intrinsically motivated participants reported a higher frequency in overall use and in all categories than those who were only extrinsically motivated. The results also showed that the students with the intrinsic motivation component used cognitive, metacognitive, affective, and social strategies significantly more frequently than those who were only extrinsically motivated.

Our findings are in the line of those from other studies which give evidences that intrinsic motivation seems to have a greater effect on strategy use than extrinsic. Learners who have an inherent interest in learning English as a foreign language use different types of LLSs more frequently than those whose motivation comes from external factors.

\section{Limitations}

The questionnaire was the instrument used in this study and the data collected are based on what the participants reported, so subjectivity can be a constraint as participants could overestimate or underestimate the frequency of use of certain strategies. Other approaches with different methods or instruments, such as interviews, diaries, class observation, could be used to obtain information, and, therefore, minimize this problem. 
Our study only describes the frequency of use of the strategies, but do not measure the effectiveness of that use, that is, if one strategy, or category of strategies, is more effective than other.

The fact that many of the participants were adults involved in the teaching field can affect their perception of the LLSs and also influence their responses.

Regarding the proficiency level factor, the main problem found when comparing the results in different studies is to state how that 'proficiency level' is measured. When talking about low- and high-proficiency levels (or learners), the question is whether those levels are the same as the levels in other studies. In our study, the proficiency levels used are the ones described in the Common European Framework of Reference for Languages (CEFRL), which gives a good standard for comparison in future studies. However, as Alhaisoni (2012) claims, '... there is a need for agreement among researchers on an international proficiency test allowing comparison between studies. This test might give researchers more accurate results about the subjects' real proficiency levels in different studies'.

In relation to the motivational aspect, the way to determine the type of motivation which our participants had was very basic (by means of a multiple choice question), and does not cover all the motivational variables that foreign language learners may have. It would be necessary to carry out a more systematic and deeper study about the effect of more specific types of motivation on the use of LLSs, as in other studies such as those by Nikoopour, et al. (2012), Xu (2011), and Ziahosseini \& Salehi (2007).

\section{Pedagogical implications}

From a pedagogical perspective, strategy instruction and its integration into the L2 learning programme can contribute to increase both teachers' and students' awareness of the different strategies. The knowledge and the use of LLSs help learners to become more autonomous, self-confident, and conscious about their own process to acquire the foreign language (Cano de Araúz, 2009; García Salinas \& Ferreira Cabrera, 2010). Learners at different proficiency levels can benefit from it.

Another important aspect we would like to highlight is the motivational factor in the process of learning a L2. Motivation, and more specifically, the intrinsic type, should be encouraged by teachers. Students have different reasons and needs when they learn a foreign language, but teachers can help them identify those purposes to improve and enhance their fulfillment in the learning process, and, therefore, make them more successful language learners.

\section{References}

Al-Buainain, H. (2010). Language learning strategies employed by English majors at Qatar University: Questions and queries. ASIATIC, Journal of English Language and Literature, 4(2), 92-120. Retrieved from http://asiatic.iium.edu.my

Alhaisoni, E. (2012). Language learning strategy use of Saudi EFL students in an intensive English learning context. Asian Social Science, 8(13), 115-127. doi:10.5539/ ass.v8n13p115 
Benson, P., \& Gao, X. (2008). Individual variation and language learning strategies. In S. Hurd \& T. Lewis (Eds.), Language learning strategies in independent settings (pp. 25-41). New York, USA: Multilingual Matters.

Cano de Araúz, O. (2009). Language learning strategies and its implications for second language teaching. Revista de Lenguas Modernas, 11, 399-411. Retrieved from http:// www.revistas.ucr.ac.cr/index.php/rlm/article/viewFile/9454/8904

Chamot, A. U. (2004). Issues in language learning strategy research and teaching. Electronic Journal of Foreign Language Teaching, 1(1), 14-26. Retrieved from http://e-flt. nus.edu.sg/v1n12004/chamot.pdf

Chang, C. (2011). Language learning strategy profile of University Foreign Language Majors in Taiwan. Electronic Journal of Foreign Language Teaching, 8(2), 201-215. Retrieved from http://e-flt.nus.edu.sg/v8n22011/chang.pdf

Chang, C.-Y., Liu, S. C., \& Lee, Y. N. (2007). A study of language learning strategies used by college EFL learners in Taiwan. Ming-Dao Journal of General Education, 2, 235-261. Retrieved from http://www.mdu.edu.tw/ ged/other\%20download/bulletin/20070319/11.pdf

Chang, H-H. (2005). The relationship between extrinsic/intrinsic motivation and language learning strategies among college students of English in Taiwan (Master's thesis). From database of Ethesys, Ming Chuan University, Taiwan.

Cohen, A. D. (1990). Language learning: Insights for learners, teachers, and researchers. New York, USA: Newbury House.

Cohen, A. D. (1998). Strategies in learning and using a second language. London, UK: Longman.

Corpas Arellano, M. D. (2010). La mujer y las estrategias de aprendizaje en la adquisición de la lengua inglesa. Revista Nebrija de Lingüística aplicada a la enseñanza de lenguas, 8(4), 3-16. Retrieved from http://www.nebrija.com/revista-linguistica/files/ revistasPDF/526a47bf8e45c_revista_completa_8.pdf .

Ellis, R. (1994). The Study of Second Language Acquisition. Oxford, UK: Oxford University Press.

Feng, C-H. (2010). A correlational study of language learning motivation and strategies of Chinese undergraduate. Canadian Social Science, 6(4), 202-209. doi: 10.3968/j. CSs.1923669720100604.022

Franco Naranjo, P. (2004). El uso de las estrategias de aprendizaje del inglés como lengua no materna: Aplicación de un cuestionario como fase previa a la enseñanza de estrategias en el aula. Porta Linguarum: Revista Internacional de Didáctica de las Lenguas Extranjeras, 2, 57-67. Retrieved from http://dialnet.unirioja.es/servlet/ articulo?codigo $=1129842$

Franco Naranjo, P., Bocanegra Valle, A., \& Díaz Martín, M. T. (2003). Análisis de las Estrategias de Enseñanza-Aprendizaje de Lenguas Extranjeras en los Cursos de los Ciclos Elemental y Superior de las Escuelas Oficiales de Idiomas (Orden de 22-03-1999). Retrieved from the Website of Junta de Andalucía, Consejería de Educación y Ciencia: http://www.juntadeandalucia.es/averroes/html/adjuntos/2008/03/06/0012/ adjuntos/estrategias_lex.pdf

Franco Naranjo, P., Pino Juste, M. R., \& Rodríguez López, B. M. (2009). Tipología y frecuencia del uso de estrategias en el aprendizaje del inglés como lengua extranjera. 
Enseñanza \& Teaching: Revista Interuniversitaria de Enseñanza, 27(2), 171-191. Retrieved from http://dialnet.unirioja.es/servlet/articulo?codigo $=3232198$

Franco Naranjo, P., Pino Juste, M. R., \& Rodríguez López, B. M. (2012). Características psicométricas de un cuestionario en español para medir estrategias de aprendizaje del inglés como lengua extranjera. Porta Linguarum: Revista Internacional de Didáctica de las Lenguas Extranjeras, 18, 27-42. Retrieved from http://www.ugr.es/ portalin/ articulos/PL_numero18/2\%20\%20Pilar\%20Franco.pdf

García Herrero, M. M. (2013). Análisis de la utilización de estrategias en el aprendizaje de la lengua extranjera. Revista de Investigación Educativa, 31(1), 53-76. doi: 10.6018/ rie.31.1.133451

García Herrero, M. M., \& Jiménez Vivas, A. (2014). Estrategias en el aprendizaje de la lengua extranjera y niveles de competencia en estudiantes universitarios de magisterio. Revista de Investigación Educativa, 32(2), 363-378. doi: 10.6018/rie.32.2.167421

García Salinas, J., \& Ferreira Cabrera, A. (2010). Entrenamiento en estrategias de aprendizaje de inglés como lengua extranjera en un contexto de aprendizaje combinado. Revista Nebrija de Lingüística aplicada a la enseñanza de Lenguas, 8(4), 17-40. Retrieved from http://www.nebrija.com/revista-linguistica/files/revistasPDF/526a47bf8e45c_ revista_completa_8.pdf

Ghani, M. (2003). Language learning strategies employed by L2 learners. Journal of Research, 4, 31-36. Retrieved from http://www.bzu.edu.pk/jrlanguages/Vol-4\%20 2003/Dr\%20Mamuna-3.pdf

Ghavamnia, M., Kassaian, Z., \& A. Dabaghi, A. (2011). The relationship between language learning strategies, language learning beliefs, motivation, and proficiency: A study of EFL learners in Iran. Journal of Language Teaching and Research, 2(5), 11561161. doi:10.4304/jltr.2.5.1156-1161

Ghee, T. T., Ismail, H. N., \& Kabilan, M. K. (2010). Language learning strategies used by MFL students based on genders and achievement groups. US-China Foreign Language, 8(1), 50-58. Retrieved from http://www.researchgate.net/publication/254255734_language_learning_strategies_use_by_MFL_used_by_students_based_on_genders_ and_achievement_groups

Grenfell, M., \& Macaro, E. (2007). Claims and critiques. In A. Cohen \& E. Macaro (Eds.), Language learner strategies (pp. 9-28). Oxford, UK: Oxford University Press.

Hong-Nam, K., \& Leavell, A. (2006). Language learning strategy use of ESL students in an intensive English learning context. System, 34(3), 399-415. doi: 10.1016/j.system.2006.02.002

Kavasoglu, M. (2009). Learning strategy use of pre-service teachers of English language at Mersin University. Procedia Social and Behavioral Sciences, 1(1), 993-997. doi: 10.1016/j.sbspro.2009.01.177

Khalil, A. (2005). Assessment of language learning strategies used by Palestinian EFL learners. Foreign Language Annals, 38(1), 108-119. doi: 10.1111/j.1944-9720.2005. tb02458.x

Lee, K., \& Oxford, R. (2008). Understanding EFL learners' strategy use and strategy awareness. Asian EFL Journal, 10(1), 7-32. Retrieved from http://www.asian-efljournal.com 
Liu, J. (2010). Language learning strategies and its training model. International Education Studies, 3(3), 100-104. doi: 10.5539/ies.v3n3p100

Lou, Y. P. (1998). English language learning strategies of junior college students in Taiwan. Studies in English Language and Literature, 3, 43-60. Retrieved from http:// www.forex.ntu.edu.tw/act/news.php?Sn=2399

Luo, J., \& Jian, X. (2004). Research on relationships among learning motivation, foreign language learning strategies and academic achievement. Research in Teaching, 27, 149-151.

Magogwe, J.M., \& Oliver, R. (2007). The relationship between language learning strategies, proficiency, age, and self-efficacy beliefs: A study of language learners in Botswana. System, 35(3), 338-352. doi: 10.1016/j.system.2007.02.003

McDonough, S. (2005). Training language learning expertise. In K. Johnson (Ed.), Expertise in Second Language Learning and Teaching (pp. 150-164). Australia: Palgrave McMillan.

Nikoopour, J., Amini Farsani, M., \& Kashefi Neishabouri, J. (2011). Language learning strategy preferences of Iranian EFL learners. Proceedings of International Conference on Social Science and Humanity, Singapore, ICSSH, 5(2), 360-364. Retrieved from http:// www.ipedr.com/vol5/no2/78-H10203.pdf

Nikoopour, J., Salimian, S., Salimian, S., \& Farsani, M. A. (2012). Motivation and the choice of language learning strategies. Journal of Language Teaching and Research, 3(6), 1277-1283. doi:10.4304/j1tr.3.6.1277-1283

O’Malley, J. M., \& Chamot, A. U. (1990). Learning strategies in second language acquisition [Adobe Digital Editions version]. doi: 10.1017/CBO9781139524490

Oxford, R. (1990). Language Learning Strategies: What Every Teacher Should Know. Boston: Heinle \& Heinle.

Oxford, R. (2002). Language learning strategies in a nutshell: Update and ESL suggestions. In J.C. Richards \& W.A. Renandya (Eds.), Methodology in language teaching: An anthology of current practice (pp. 124-132) [Adobe Digital Editions version]. doi: 10-1017/CB0980511667190.018

Peng, I. N. (2001). EFL motivation and strategy use among Taiwanese senior high school learners (Unpublished master's thesis). National Taiwan Normal University, Taiwan.

Radwan, A. A. (2011). Effects of L2 proficiency and gender on choice of language learning strategies by university students majoring in English. The Asian EFL Journal, 13(1), 114-162. Retrieved from http://www.asian-efl-journal.com/PDF/March-2011-aar.pdf

Razak, N. Z. B. A., \& Babikkoi, M. A. (2014). English language learning strategies of Malaysian secondary school students: Implication for inter-cultural communication. Sociology Mind, 4, 206-212. doi: 10.4236/sm.2014.42020

Risueño Martínez, J. J., Vázquez Pérez, M. L. Hidalgo Navarrete, J., \& de la Blanca de la Paz, S. (2014). Estrategias de aprendizaje: Cómo aprendo inglés?. Recuperado de: https://docs.google.com/a/fundacionsafa.es/forms/d/1Rud0GCYr-Y_OcYTlF8G2GAKVRC84XrqEp1qRaAHH7XA/viewform

Roncel Vega, V. (2007). Aprende-le: Inventario de estrategias de aprendizaje para la lengua española. Revista electrónica de didáctica / español lengua extranjera, 9, 1-14. Retrieved from http://hdl.handle.net/11162/72126 
Rubin, J. (1975). What the "good language learner" can teach us. TESOL Quarterly, 9(1), 41-51. doi: 10.2307/3586011

Rubin, J. (1987). Learner Strategies in Language Learning. New Jersey, USA: Prentice Hall.

Takeuchi, O. (2003). What can we learn from good language learners: A qualitative study in the Japanese foreign language context. System, 31(3), 385-392. doi: 10.1016/ S0346-251X(03)00049-6

Tercanlioglu, L. (2004). Exploring gender effect on adult foreign language learning strategies. Issues Educational Research, 14(2), 181-193. Retrieved from http://www. iier.org.au/iier14/tercanlioglu.html

Vandergrift, L. (1997). The comprehension strategies of second language (French) listeners: A descriptive study. Foreign Language Annals, 30(3), 387-409. doi: 10.1111/j.19449720.1997.tb02362.x

Wenden, A. (1991). Learner strategies for learner autonomy. Englewood Cliffs, NJ, USA: Prentice Hall.

Wenden, A., \& J. Rubin (1987) (Eds.). Learner strategies in language learning. Englewood Cliffs, NJ, USA: Prentice Hall.

Wharton, G. (2000). Language learning strategy use of bilingual foreign language learners in Singapore. Language Learning, 50(2), 203-243. doi: 10.1111/0023-8333.00117

Wu, Y. L. (2008). Language learning strategies used by students at different proficiency levels. Asian EFL Journal, 4(10), 75-95. doi: 10.5539/ijel.v1n2p203

$\mathrm{Xu}, \mathrm{X}$. (2011). The relationship between language learning motivation and the choice of language learning strategies among Chinese graduates. International Journal of English Linguistics, 1(2), 203-212. doi:10.5539/ijel.v1n2p203

Yang, M.N. (2007). Language learning strategies for college students in Taiwan: Investigating ethnicity and proficiency. The Asian EFL Journal, 9(2), 35-57. Retrieved from http://www.asian-efl-journal.com/June_2007_EBook_editions.pdf\#page=35

Yin, C. (2008). Language learning strategies in relation to attitudes, motivations, and learner beliefs: investigating learner variables in the context of English as a foreign language in China (Ph.D. Thesis, University of Maryland, College Park). Retrieved from http:// hdl.handle.net/1903/8258

Ziahosseini, S. M., \& M. Salehi. (2007). An investigation of the relationship between motivation and language learning strategies. Pazhuhesh-e Zabanha-ye Khareji, 41(Special Issue), 85-107. Retrieved from http://www.sid.ir/en/VEWSSID/J_pdf/91920084105.pdf

Zhou, C., \& Intaraprasert, C. (2015). Language learning strategies employed by Chinese English-major pre-service teachers in relation to gender and personality types. English Language Teaching, 8(1), 155-169. doi:10.5539/elt.v8n1p155

Fecha de recepción: 18/07/2015

Fecha de revisión: 19/07/2015

Fecha de aceptación: 30/09/2015 
